\title{
Transatlantica
}

Revue d'études américaines. American Studies Journal

\section{Places and Cultures of Capitalism: Histories from the Grassroots}

\section{Elsa Devienne and Andrew Diamond}

\section{(2) OpenEdition \\ Journals}

Electronic version

URL: https://journals.openedition.org/transatlantica/15911

DOI: 10.4000/transatlantica. 15911

ISSN: 1765-2766

\section{Publisher}

Association française d'Etudes Américaines (AFEA)

Electronic reference

Elsa Devienne and Andrew Diamond, "Places and Cultures of Capitalism: Histories from the Grassroots", Transatlantica [Online], 2 | 2020, Online since 01 February 2021, connection on 01 February 2023. URL: http://journals.openedition.org/transatlantica/15911 ; DOI: https://doi.org/ 10.4000/transatlantica.15911

This text was automatically generated on 1 February 2023.

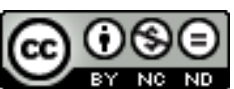

Creative Commons - Attribution-NonCommercial-NoDerivatives 4.0 International - CC BY-NC-ND 4.0 https://creativecommons.org/licenses/by-nc-nd/4.0/ 


\title{
Places and Cultures of Capitalism: Histories from the Grassroots
}

\author{
Elsa Devienne and Andrew Diamond
}

1 The strange career of capitalism the concept has taken a new twist since the global financial crisis of 2007-2010 shook the foundations of the capitalist system and had pundits across the planet speculating about its future. In the aftermath of the disaster, the terms "capitalism" and "capitalist" began to enter into the parlance of our times, bandied about by a range of actors-from activists in the streets to journalists and opinion-makers to professors in the most elite universities to political leaders and leading businessmen. There were some earlier stirrings within the circles of the intelligentsia-in 2006 Julia Ott became the first professor recruited specifically in "the history of capitalism"; in 2007 Naomi Klein's The Shock Doctrine: The Rise of Disaster Capitalism became an international bestseller; and in 2008 Harvard University created its Program on the Study of US Capitalism. But capitalism the concept hit the big time beginning late in 2011, when the Occupy Wall Street Movement and its "99 percent" rhetoric thrust it squarely onto the landscape of mainstream political discourse in the United States and beyond, particularly within the English-speaking world. While the movement's message was subject to debate, with some observers interpreting it as a protest against Wall Street corruption and greed, and others viewing it more broadly and ambitiously as anti-capitalist, Occupy had certainly contributed to making "capitalism," as philosopher Slavoj Žižek wrote in the Guardian, "the name of the problem."

2 Several months later, in April 2013, the New York Times ran a front-page article under the headline "In History Departments It's Up With Capitalism" covering the new excitement for "the history of capitalism" at some leading universities in the United States, including Cornell, which, the article revealed, had organized a history of capitalism summer "boot camp" replete with history of capitalism t-shirts for participants (Schuessler). Then, some two years later in a truly breathtaking turn, French economist Thomas Piketty's nearly 700-page book Capital in the Twenty-First Century became a New York Times bestseller and reached number one on Amazon. For a 
couple of months Piketty was commonly referred to in the media as a "rockstar economist," making a number of television appearances, including on Comedy Central's The Colbert Report. "My guest tonight has a new book that blows the lid off income inequality," Colbert quipped, "but don't worry it's 40 bucks-poor people will never know" ("Capitalisn't"). Hollywood was, of course, not to be left out of this hip new trend as a range of industry stars got behind a number of capitalism-themed movie projects directed at exposing the madness of the system-Charles Ferguson's 2010 Best Documentary Oscar winner Inside Job, narrated by Matt Damon; Martin Scorsese's 2013 film The Wolf of Wall Street, and the 2015 blockbuster The Big Short, winner of the Oscar for Best Adapted Screenplay (and nominated for numerous others, including Best Picture and Best Director).

3 All this was the backstory to the insurgency of self-proclaimed democratic socialist Bernie Sanders during the Democratic primaries of 2016 and then the surprising 2018 congressional election victory of democratic socialist fellow traveler Alexandria OcasioCortez, who quickly became far and away the most followed member of Congress on Twitter. Sanders and Ocasio-Cortez have played leading roles in bringing about a new candor about capitalism within the Democratic Party and its circle of big donors following the retreat from such language amidst the socialist-baiting of the early Obama years. Ocasio-Cortez has called capitalism "irredeemable" (Warren), legendary billionaire investor and Democratic fundraiser Warren Buffet publicly expressed support for Sanders by stating that "We ought to do better by the people that get left behind by our capitalist system" (Zeballos-Roig), and in distinguishing herself from Sanders in 2018, Senator Elizabeth Warren, another prominent member of the Democratic Party's left flank, described herself as "capitalist to the bone" (Foer). As Warren's oft-quoted quip suggests, the rhetoric among top Democratic candidates had become so openly critical of capitalism that mainstream politicians like Warren had to remind voters (and donors) that they're still pro-capitalism after all.

Capitalism the concept has thus evolved into a form of symbolic, cultural, and political capital over the past decade, and the rising value of this capital has driven the emergence of what has become one of the most vibrant subfields in the US historical profession-the so-called "new history of capitalism." The rush of activity around this subfield has led to the development of programs, centers, conferences, book series, and a flurry of course offerings at prestigious institutions like Harvard, Brown, the University of Chicago, Columbia, Princeton, Yale, Cornell, and the New School for Social Research. As Thomas Jessen Adams has poignantly suggested, the institutional enthusiasm about this new subfield has likely had something to do with the fact that it held the potential of attracting students and funding in a moment when the humanities and social sciences were fighting for enrollment and against accusations of obsolescence. But for the cohort of scholars identifying with the "new history of capitalism," there has also been the heartfelt belief that this project of gathering new methodologies and approaches around the study of capitalism will enable us to clarify its dynamics and workings, horizontally and vertically, from bottom to top. Indeed, around the time the New York Times proclaimed the triumphant rise of the "new history of capitalism," a number of scholars identifying with this historiographical movement began using blogs, forums, review essays, and the introductions of collective works to assert what was new about this subfield and to explain its origins (Beckert et al.). 
In terms of what was new, most agreed, first and foremost, on the badly needed return to political economy as a category of analysis, and secondly on an emphasis on what Sven Beckert and Christine Desan refer to as the "experiential dimension" of capitalism -that is, the story of how capitalism has been lived from the bottom up (11). The proponents of the "new history of capitalism" also generally share an embrace of interdisciplinarity and a spirit of methodological inclusion derived from a reluctance to impose any kind of rigid theoretical definition of capitalism itself. As Seth Rockman wrote in one of the seminal field review essays: "If the goal is to figure out what capitalism is and how it has operated historically, scholars seem willing to let capitalism float as a placeholder while they look for ground-level evidence of a system in operation" (442). As for the story of origins, the explanation offered from nearly all of the subfield's founders related to two key factors that had allegedly hampered the ability of historians to effectively study and discuss capitalism in all its complexity and to challenge the neoclassical economic doxa that had naturalized it in the United States: first, the move towards cliometrics and the use of abstract quantitative approaches in the field of economic history, which caused economic history to move out of history departments and into economics departments (Beckert and Desan; Barreyre and Blin); and second, the cultural turn and postmodern shift of the 1980s and 1990s, which led to an explosion of scholarship on the identities, experiences, and movements of the oppressed-racial and sexual minorities, women, labor-but which turned attention away from economic matters (Hyman). As Julia Ott and William Milberg succinctly put it in "Capitalism Studies: A Manifesto," the mission statement for the New School's Robert L. Heilbroner Center for Capitalism Studies:

Economists cut economies loose from society, institutions, culture, and history. They repositioned their discipline upon models that assumed that rational, utilitymaximizing individual parts represented and explained the behavior of the economy-as-a-whole. Many social scientists-especially in political scienceembraced these rational-actor models. Others joined historians and humanities scholars in the "cultural turn." They struck out for new worlds of culture, those ever-shifting systems of language and meaning, symbols and signifiers, identity and consciousness that produce and reproduce power. In doing so, however, these academics largely abandoned questions of class and ceded the terrain of economics. (Ott and Milberg)

Observing the frequency of references made by adherents of the "new history of capitalism" to some variant of this originary story, Nan Enstad argues that it represents nothing short of a "jeremiad" promising redemption in the turn away from the cultural and social towards the economic. "I notice this jeremiad not only in the influential published sources cited here," Enstad writes, "but also in myriad casual professional conversations and on social media, where the idea that 'social and cultural' historians lost interest in 'the economy' in the 1980s and 1990s is offered as a non-controversial, nearly self-evident view" (85-83). Enstad's ultimate point in her sobering critique of the "new history of capitalism" is not to assail its reflexive denigration-at times implied, in others quite explicit-of the social and cultural history of race, gender, labor, and sexuality, but rather to call out the analytical damage done by "juxtaposing 'economy' against 'social and cultural."' Such thinking, she explains, assumes that the social and cultural, on the one hand, and the economic, on the other, are separate categories and "diametrically opposed aspects of life," leading both to a flawed understanding of what social and cultural history has offered to the history of capitalism, and, more 
importantly, to a tendency to universalize "economy" in a way that allows its "tacit legacy of race and gender" to live on $(88 ; 87 ; 94)$.

6 Enstad is hardly alone in critiquing the "new history of capitalism" for its conceptual problems and historical blind spots when it comes to reckoning with the role and place of gender, race, and class in capitalism's long history. Writing in the Journal of the Early Republic in 2016, Amy Dru Stanley asked "Why is the emergent grand narrative of a 'new' history of capitalism so blind to the problem of sex difference?" (343). Indeed, one of the critical breakthroughs of the "new history of capitalism," according to some leading voices within the cohort, has been the rewriting of the relationship between slavery and capitalism in US history by illuminating the role of finance in linking together northern capitalism to southern slavery; but, as Stanley argues, this rendering has left "unasked how the productive and reproductive work of women-free and unfree-created wealth across the country" (348). Moreover, Peter Hudson, in his contribution to the 2014 field-defining "interchange" in the Journal of American History, expressed misgivings about the fact that while "the history of capitalism appears to mark a triumphal defeat of postmodernism, difference, fracture, and the 1990s identity politics," neither the historiography of black women nor of the carceral state had figured prominently in discussions defining the field and its agenda (Beckert et al. 504-505). Finally, Thomas Jessen Adams and Paul Kramer have each taken the "new history of capitalism" to task for its elision of "labor struggle" and class "power relations." Adams goes so far as to suggest that the traction of the "new history of capitalism" lies in the marginal place it has attributed to labor struggle, while Kramer suggests that the "effective brand" the subfield has become lies in its very ability to avoid political questions that would trouble those who "embraced capitalist power relations and sought managerial how-to answers" (333).

7 The "new history of capitalism" has thus come under considerable criticism related to its uneasy relationship with social and cultural history, and to how this awkward relationship has shaped its reluctant engagement with the analytical categories of race, gender, sexuality, and class. This is not to say that the practitioners of this new subfield disregard these categories altogether. The body of field-defining literature makes frequent references to foundational works like Eric Williams's 1944 classic Capitalism and Slavery, Joan Scott's seminal 1986 article "Gender: A Useful Category of Analysis," and E.P. Thompson's 1963 landmark The Making of the English Working Class, and most interventions make sure to pound the table on the importance of gender and race in the "new history of capitalism." But, aside from assertions about the pathbreaking nature of the slavery-as-capitalism project and the presence of Amy Dru Stanley's brilliant work on gender-in two prominent "new history of capitalism" collections (Zakim and Kornblith; Beckert and Desan) hers is the only chapter of its kind-the "new history of capitalism" has not yet made a compelling case that it has, in the words of Julia Ott, "retained the analytic emphasis on gender, ethnicity, and race" left to it from the social and cultural history of the 1980s onward (Beckert et al. 505). Despite the emphasis on inclusion, for a subfield to be a subfield there is a need for boundaries, and all the name-dropping that has occurred in the field-defining essays surely has something to do with determining who and what belongs, and who and what doesn't.

8 The dossier of articles to follow has its genesis in a feeling shared by its editors and other scholars joining them in the organization of a series of workshops in 2017 and 2018 around the theme "Places and Cultures of Capitalism: New Histories from the 
Grassroots" that those sketching out the future of the "new history of capitalism" had been drawing these boundaries too narrowly. ${ }^{1}$ We saw our own work as building upon a range of interdisciplinary-minded studies in social, cultural, political, urban, and environmental history that we felt offered critical interventions into the history of capitalism, but whose titles seemed to appear nowhere within the canon being established by the "new history of capitalism" conversation.

Part of the problem, to our minds, was that few of the works that were coming to define this new subfield crossed into the second half of the twentieth century, an era that witnessed dramatic structural and political transformations-suburbanization, deindustrialization, urban renewal, ghettoization, mass incarceration, gentrification, the explosion of the tourism and leisure economy, the decline of organized labor, minority empowerment movements, homeowners' and taxpayers' rebellions-that reshaped metropolitan political economies and political cultures throughout the United States. ${ }^{2}$ How, for example, can one write the history of capitalism in the postwar era from bottom to top without writing about the extractive racial capitalism driven by the real estate industry and the state, the strategies people of color deployed to contest and survive it, and the political order that made this situation possible? ${ }^{3}$ Why hasn't the "new history of capitalism" yet incorporated into its groundwork such contributions on the history of racial capitalism as Robin D.G. Kelley's earlier work on the black working class (and his more recent project on racial capitalism), KeeangaYamahtta Taylor's recent scholarship on black homeownership and "predatory inclusion," and Rhonda Y. Williams's study of the grassroots activism of low-income African American women? ${ }^{4}$ And, how can we understand racial capitalism in the second half of the twentieth century without drawing heavily from the abundantly rich well of scholarship on homeowner populism, taxpayer revolts, and the upsurge of conservative grassroots mobilization that paved the way for the ideological triumph of a package of market-oriented languages and logics-consumer rights, colorblindness, meritocracy, "laissez-faire racism," "race-inflected neoliberalism." 5 Perhaps in part due to the reluctance of the "new history of capitalism" conversation to engage with the new generation of historiography on racial capitalism, this project exploring the relationship between capitalism and race in the modern United States is developing largely apart from it, led by historians like N.D.B. Connolly and Destin Jenkins, among others (Connolly; Jenkins and Leroy). ${ }^{6}$

The "new history of capitalism" has thus hardly touched the evolution of capitalism in urban spaces in the second half of the twentieth century, an era that witnessed the rise of a political and economic order that a growing number of historians describe as neoliberal (Diamond and Sugrue; Gerstle; Phillips-Fein and Neumann). Indeed, paralleling the explosion of capitalism talk after 2008 was the increasing currency of neoliberalism as an analytical concept in the social sciences. While sociologists, political scientists, and geographers rather quickly adopted the term for their analytical toolboxes, a number of historians pushed back against its lack of theoretical and historical precision, including Daniel T. Rodgers, who referred to it as a "linguistic omnivore of our times, a neologism that threatens to swallow up all the other words around it." Some historians today still soft-pedal around the term, using it tentatively and often accompanied by apologies for its imperfections. However, despite such resistance to the concept, neoliberalism, according to Brent Cebul, Lily Geismer, and Mason Williams, "has moved to the center of twentieth-century US political history in the past decade" (8). Prominent elder political historians like Gary Gerstle and Nelson 
Lichtenstein employ the term to identify the political order that succeeded the New Deal order, and an increasing number of urban historians are putting it at the core of their analyses about policy and politics in metropolitan spaces (Gerstle; Huret et al.; Neumann; Weaver; Diamond; Taft). And yet, neoliberalization as a force transforming metropolitan political cultures from modes of governance down to grassroots politics has had a marginal place in discussions surrounding the "new history of capitalism."

11 Each of the articles to follow, in one way or another, contributes to and complicates our understanding of different facets of the long march of neoliberalism within the broader history of capitalism. And they do so in ways that build upon new approaches to historicizing the neoliberal shift. First, if historians have embraced neoliberalism as a conceptual scaffolding, they have argued for historicizing its evolution over the longue durée, as a process that unraveled gradually and unevenly over the course of the twentieth century, rather than occurring as a "takeover" or "turn" in the 1970s (Cebul et al.; Diamond and Sugrue). ${ }^{7}$ Secondly, histories of neoliberalization have recently focused on bottom up social and cultural approaches, a move that has further undermined the inevitably top-down understanding of a takeover engineered by international financial agents and focused attention on how market rationalities and economizing logics became embedded within the fabric of political life. This project, for example, was presented in a recent "special section" of the Journal of Social History entitled "Social Histories of Neoliberalism," which argued for the importance of using social history as "a way to explain the legitimacy of neoliberalism as a political and social order" (Lebovic 5).

Several of the articles collected here move in this direction. Anaïs Lefèvre's work on the uses of self-esteem discourse in legitimating carceral labor in prisons, Brenda Parker and George Katito's thinking on the role of gender and sexuality in shaping the political economies and modes of governance of US cities, Natalia Mehlman Petrzela's excavation of the origins of a fitness culture and market, and Andrew Kahrl's focus on the human cost of "coastal capitalism"-the workings of "cultural transformation" and "commodification" that wiped away communities-all represent the kind of multilevel, yet bottom-heavy interventions in the social and cultural history of neoliberalization that promise to texture and extend the "new history of capitalism." Indeed, these interventions bring this history into a range of "new" places-prison workplaces, $\mathrm{LGBTQ}+$ communities, fitness clubs, and island communities. But they enter these places with a keen eye on how the state and political economy shape their conditions and circumstances. Above all, they illuminate the promises of an approach to the history of capitalism that refuses to disentangle the social and cultural from the economic and the political.

This is no less the case with David Huyssen's study of how the modern hedge fund grew out of the context of General Electric's environs in Schenectady, New York, or with Jeffrey Helgeson's story of how the political activism of writer Fanny Howe and artist Dana C. Chandler, Jr. created alternative political possibilities and futures in neoliberal Boston. Huyssen's micro-level exploration of the "background conditions" of Alfred Jones's invention of the hedge fund, and Helgeson's move to put a writer and an artist at the center of a story about contesting neoliberalization offer fresh approaches to the history of capitalism, while at the same time challenging some of the subfield's foundational precepts. As Jürgen Kocka reminds us, before capitalism became an analytical concept, it was a polemical term, "a concept of difference [...] used to identify 
and critically underline certain features of the present, in contrast to what it was thought to have been in previous times, and to what it might become under socialism in the future" (80). Huyssen thus shows how imposing a history of capitalism framework on the development of the hedge fund causes us to misunderstand the "simultaneity of socialism and capitalism" and to overlook how socialist aspirations could even play an important role in the making of this capitalist financial tool par excellence. Helgeson's account of the work of leftist intellectuals and artists provides a similar reminder of the importance of retaining contingency and possibility in the face of the kind of totalizing narratives that the histories of capitalism and neoliberalism can become. In Boston and beyond, people on the ground worked to construct alternative spaces and cultures in the face of the economizing rationalities that were reshaping their neighborhoods and communities, and these local histories are critical to the broader history of capitalism.

14 Several articles in this dossier also reveal the critical insights offered by a number of subfields that the "new history of capitalism" has largely overlooked. Andrew Kahrl's study of the destruction of the Daufuskie Island community at the hands of real estate developers, tax assessors, state courts, and federal engineers highlights the resistance of black landowners and residents against the tide of "coastal capitalism." Yet the Daufuskie story ultimately demonstrates how such attempts at preserving the community and its alternative economy failed when faced with a real estate industry solidly backed by local, state, and federal authorities. As such, Kahrl's article shines a light on the construction of a discourse of inevitability surrounding the privatization and commodification of coveted natural sites, which served and reinforced the neoliberalization process, and how victims of capitalism were indoctrinated into its logic and became agents in its formation and extension. Yet Kahrl's article also brings into the picture what he has called elsewhere "the inextricability of environmental and human exploitation" (Kahrl, 2012 5). The arrival of coastal capitalists in the 1970s and the subsequent dismantling of Daufuskie's commons brought rapid destruction to the island's fragile ecologies at the same time as it dismantled "the will and means of collective action." In highlighting this process, Kahrl's article represents a muchneeded analysis of the fundamentally contradictory logics of capitalism-which relies on predictability, short-term gains, and never-ending growth-and the environmentwhich remains difficult to fully control and is ultimately finite in its resources. Despite references to William Cronon's classic Nature's Metropolis in many of the "new history of capitalism" field-defining pieces, the environment and environmental history remain remarkably short-changed in the field as a whole, at least in the ways in which it has so far been understood. Recent works point to the exciting insights that can emerge at the intersections of the two, whether it involves looking at coastal lands and arctic frontiers that defied capitalist logics born in more forgiving environments, the privatization of public space and the concentration of natural amenities in the hands of the elite, or global networks of resource extraction and distribution (Kahrl, 2012; 2018; Demuth; Elmore; Jobson).

15 The "new history of capitalism," moreover, would also benefit from engaging with the recent scholarship on the carceral state. Anaïs Lefèvre's study of the penetration of the language of "self-esteem" in 1970s and 1980s prison work programs cogently demonstrates the ties that bind together the neoliberalization process to the expansion of the carceral state. Yet unlike the many fine works that have approached the emergence of the "prison-industrial complex" emerging out of the fields of sociology 
and political and social history (Camp; Harcourt; Murch; Diamond and Sugrue; H.A. Thompson; Wacquant), Lefèvre uses the tools of cultural history to track the ascendance-both in political discourse and popular culture-of self-esteem rhetoric as a seemingly benevolent tool to shape prisoner psyche. Here, again, we identify one of the legitimizing discourses through which neoliberal logics came to be accepted by a wide range of actors: by putting the onus on the (flawed) individual to restore their sense of self and become a functioning member of society, Lefèvre shows how a psychological concept turned into a managerial recipe for success both justified exploitative labor prison practices and served to rationalize the appalling poverty and unemployment rates among ex-convicts.

Finally, Natalia Mehlman Petrzela's article on the origins of the modern American fitness culture and George Katito's interview of Brenda Parker on the role of masculinities in shaping urban governance in neoliberal cities in the US and Europe point towards another blind spot of the "new history of capitalism," namely the relationship between markets and urban economies and the history of gender, sexuality, and the body. Historians of consumption and the rise of consumer capitalism have done much over the past twenty years to portray women, people of color, and gay men and lesbians as dynamic actors whose participation in the marketplace-as consumers or entrepreneurs-allowed them to shape their individual and collective identities as well as protest their exclusion from the body politic (Peiss; Cohen; Kelley; Weems). Yet, this scholarship is rarely mentioned as an inspiration by historians who claim the "new history of capitalism" label. Even so, they have paved the way for new studies that put the gendered, queer, and racialized body squarely at the center of the history of capitalism (Schrank, 2018; Johnson). Mehlman Petrzela's study of early twentieth-century entrepreneurs of physical culture contributes to this new wave of scholarship by showing how these men and women marketed their bodies and their products by linking the pursuit of exercise to moral virtue. As Sarah Schrank reminds us, from the early twentieth century onwards physical appearance became a "critical factor in the successful navigation of urban capitalism" (2012 638). More generally, American cities and their political economies have been powerfully shaped by gender hierarchies and values, and by sexuality. As Brenda Parker's Masculinities and Markets demonstrates, the recent rise of new urbanism in urban governance and its accompanying discourses celebrating the "creative class" tend to privilege the views, desires, and circumstances of elite white men, deepening the socioeconomic inequities that affect low-income mothers and minorities. Interestingly, as George Katito argues, this new style of urban governance spread from the US to European cities. While some aspects of the American influence on urban practices and imaginaries were perceived as liberating for gay white men in Paris and London, the transfer was not as beneficial for those who occupied "subordinated masculinities and sexualities." Katito and Parker's discussion ultimately points at the continued need for analyses of the neoliberal city that are both attentive to the ground-level effects of race, gender, and sexuality and to global circulations of urban and economic models.

17 Taken together, the articles in this special issue suggest that the "new history of capitalism" has much to gain from entering certain places it has so far neglectedprisons, gyms, fragile ecosystems, LGBTQ+ communities-and foregrounding the cultures-self-esteem rhetoric, new urbanism ideals, wellness discourses-that helped naturalize capitalism and legitimize the rise of neoliberalism. 


\section{BIBLIOGRAPHY}

ADAMS, Thomas Jessen. "Writing the History of Capitalism with Class." Nonsite.org, no. 29, 9 September 2019, nonsite.org/writing-the-history-of-capitalism-with-class/\#foot_src_18-12062.

Accessed 28 January 2021.

BARREYRE, Nicolas, and Alexia BLIN. “À la redécouverte du capitalisme américain.” Revue d'histoire du XIX ${ }^{e}$ siècle, no. 54, 2017, p. 135-148.

BECKERT, Sven, Augus BURGIN, Peter James HUDSON, Louis HYMAN, Naomi LAMOREAUX, Scott MARLER, Stephen MIHM, Julia OTT, Philip SCRANTON, and Elizabeth TANDY SHERMER. "Interchange: The History of Capitalism." The Journal of American History, vol. 101, no. 2, 2014, p. 503-536.

BECKERT, Sven, and Christine DESAN (eds.). American Capitalism: New Histories. New York: Columbia University Press, 2018.

BOBO, Lawrence, James R. KLUEGEL, and Ryan A. SMITH, "Laissez-Faire Racism: The Crystallization of a Kinder, Gentler, Antiblack Ideology." Racial Attitudes in the 1990s. Eds. Steven A. Tuch and Jack K. Martin. Westport: Praeger, 1997.

CAMP, Jordan T. Incarcerating the Crisis: Freedom Struggles and the Rise of the Neoliberal State. Oakland: University of California Press, 2016.

“Capitalisn't: Capital Isn't in the $21^{\text {st }}$ Century.” 1 February 2018, review.chicagobooth.edu/economics/2018/article/capitalisn-t-capital-isn-t-21st-century. Accessed 28 January 2021.

CEBUL, Brent, Lily GEISMER, and Mason WILLIAMS. Shaped by the State: Toward a New Political History of the Twentieth Century. Chicago: University of Chicago Press, 2019.

COHEN, Lizabeth. A Consumers' Republic: The Politics of Mass Consumption in Postwar America. New York: Knopf, 2003.

CONNOLLY, N.D.B. A World More Concrete: Real Estate and the Remaking of Jim Crow South Florida. Chicago: University of Chicago Press, 2014.

CRONON, William. Nature's Metropolis: Chicago and the Great West. New York: Norton, 1991.

DAWSON, Michael C. Not in Our Lifetimes: The Future of Black Politics. Chicago: University of Chicago Press, 2011.

DAWSON, Michael C., and Megan Ming FRANCIS. "Our Vision." www.raceandcapitalism.com/our-vision.

Accessed 2 February 2021.

DEMUTH, Bathsheba. Floating Coast: An Environmental History of the Bering Strait. New York: Norton, 2019.

DIAMOND, Andrew J. Chicago on the Make: Power and Inequality in a Modern City. Oakland: University of California Press, 2017.

DIAMOND, Andrew J., and Thomas J. SUGRUE (eds.). Neoliberal Cities: The Remaking of Postwar Urban America. New York: New York University Press, 2020.

ELMORE, Bartow J. Citizen Coke: The Making of Coca-Cola Capitalism. New York: Norton, 2014. 
ENSTAD, Nan. "The 'Sonorous Summons' of the New History of Capitalism, Or, What Are We Talking about When We Talk about Economy?" Modern American History, vol. 2, iss. 1, 2019, p. 83-95.

FOER, Franklin. “Elizabeth Warren's Theory of Capitalism.” The Atlantic, 28 August 2018, www.theatlantic.com/politics/archive/2018/08/elizabeth-warrens-theory-of-capitalism/ $568573 /$.

Accessed 28 January 2021.

GERSTLE, Gary. “The Rise and Fall (?) of America's Neoliberal Order.” Transactions of the RHS, vol. 28, p. 241-264.

HARCOURT, Bernard E. The Illusion of Free Markets: Punishment and the Myth of Natural Order. Cambridge, MA: Harvard University Press, 2011.

HARVEY, David. A Brief History of Neoliberalism. New York: Oxford University Press, 2005.

HURET, Romain, Nelson LICHSTENSTEIN, and Jean-Christian VINEL. "Introduction: The New Deal: A Lost Golden Age?" Capitalism Contested: The New Deal and Its Legacies. Eds. Romain Huret, Nelson Lichtenstein, and Jean-Christian Vinel. Philadelphia: University of Pennsylvania Press, 2020.

HYMAN, Louis. “Why Write the History of Capitalism?” Symposium Magazine, 8 July 2013, www.symposium-magazine.com/why-write-the-history-of-capitalism-louis-hyman/. Accessed 28 January 2021.

JENKINS, Destin, and Justin LEROY (eds.). Histories of Racial Capitalism. New York: Columbia University Press, 2021.

JOBSON, Ryan Cecil. "Dead Labor: On Racial Capital and Fossil Capital." Histories of Racial Capitalism. Eds. Justin Leroy and Destin Jenkins. New York: Columbia University Press, 2021.

JOHNSON, David K. Buying Gay: How Physique Entrepreneurs Sparked a Movement. New York: Columbia University Press, 2019.

KAHRL, Andrew A. The Land Was Ours: African American Beaches from Jim Crow to the Sunbelt South. Cambridge, MA: Harvard University Press, 2012.

KAHRL, Andrew A. Free the Beaches: The Story of Ned Coll and the Battle for America's Most Exclusive Shoreline. New Haven: Yale University Press, 2018.

KATITO, George. "Pink Atlantic: American Global Power and the Construction of Gay Identities in Paris and London (1940s-1980s).” PhD dissertation, Sorbonne Université, 2020.

KELLEY, Robin D.G. Race Rebels: Culture, Politics, and the Black Working Class. New York: Free Press, 1996.

KLEIN, Naomi. The Shock Doctrine: The Rise of Disaster Capitalism. New York: Knopf, 2007.

KOCKA, Jürgen. "Capitalism and Its Critics: A Long-Term View." The Lifework of a Labor Historian: Essays in Honor of Marcel van der Linden. Eds. Ulbe Bosma and Karin Hofmeester. Leiden: Brill, 2018.

KRAMER, Paul. "Embedding Capital: Political-Economic History, the United States, and the World." Journal of the Gilded Age and Progressive Era, vol. 15, no. 3, 2016, p. 331-362.

KRUSE, Kevin. White Flight: Atlanta and the Making of Modern Conservatism. Princeton: Princeton University Press, 2006.

LASSITER, Matthew D. The Silent Majority: Suburban Politics in the Sunbelt South. Princeton: Princeton University Press, 2006. 
LEBOVIC, Sam. "Introduction: Social Histories of Neoliberalism." Journal of Social History, vol. 53, no. 1, 2019, p. 1-6.

MORETON, Bethany. To Serve God and Wal-Mart: The Making of Christian Free Enterprise. Cambridge, MA: Harvard University Press, 2009.

MURCH, Donna. "The Color of War: Race, Neoliberalism, and Punishment in Late TwentiethCentury Los Angeles." Neoliberal Cities: The Remaking of Postwar Urban America. Eds. Andrew J. Diamond and Thomas J. Sugrue. New York: New York University Press, 2020, p. 128-153.

NEUMANN, Tracy. Remaking the Rust Belt: The Postindustrial Transformation of North America. Philadelphia: University of Pennsylvania Press, 2016.

OTT, Julia, and William MILBERG, “Capitalism Studies: A Manifesto.” Publicseminar.org, 17 April 2014, publicseminar.org/2014/04/capitalism-studies-a-manifesto/\#.U1Apq14uww_. Accessed 28 January 2021.

PARKER, Brenda K. Masculinities and Markets: Raced and Gendered Urban Politics in Milwaukee. Athens: University of Georgia Press, 2017.

PEISS, Kathy. Hope in a Jar: The Making of America's Beauty Culture. New York: Henry Holt, 1998.

PHILLIPS-FEIN, Kim. Invisible Hands: The Businessmen's Crusade against the New Deal. New York: Norton, 2009.

PHILLIPS-FEIN, Kim, and Tracy NEUMANN. "Neoliberalism: Kim Phillips-Fein and Tracy Neumann Unpack the Knotty Realities and History of the Ubiquitous Term." The Metropole, June 2019, themetropole.blog/2019/06/05/neoliberalism-kim-phillips-fein-and-tracy-neumann-unpackthe-knotty-realities-and-history-of-the-ubiquitous-term/.

Accessed 2 February 2021.

PIKETTY, Thomas. Capital in the Twenty-First Century. Cambridge, MA: Belknap Press, 2017.

ROCKMAN, Seth. "What Makes the History of Capitalism Newsworthy?" Journal of the Early Republic, vol. 34, no. 3, 2014, p. 439-466.

RODGERS, Daniel T. "The Uses and Abuses of 'Neoliberalism'.” Dissent, Winter 2018, www.dissentmagazine.org/article/uses-and-abuses-neoliberalismdebate.

Accessed 2 February 2021.

SCHRANK, Sarah. "Naked Houses: The Architecture of Nudism and the Rethinking of the American Suburbs." Journal of Urban History, vol. 38, no. 4, 2012, p. 635-661.

SCHRANK, Sarah. "The Late Capitalist Physique." Modern American History, vol. 1, no. 3, 2018, p. 431-435.

SCHUESSLER, Jennifer. “In History Departments It's Up With Capitalism.” The New York Times, 7 April 2013, www.nytimes.com/2013/04/07/education/in-history-departments-its-up-with-capitalism.html. Accessed 28 January 2021.

SCOTT, Joan. "Gender: A Useful Category of Analysis." The American Historical Review, vol. 91, no. 5, 1986, p. 1053-1075.

STANLEY, Amy Dru. "Histories of Capitalism and Sex Difference." Journal of the Early Republic, vol. 36, no. 2, 2016, p. 343-350. 
TAFT, Chloe E. From Steel to Slots: Casino Capitalism in the Postindustrial City. Cambridge, MA: Harvard University Press, 2016.

TAYLOR, Keeanga-Yamahtta. Race for Profit: How Banks and the Real Estate Industry Undermined Black Homeownership. Chapel Hill: University of North Carolina Press, 2019.

THOMPSON, Edward P. The Making of the English Working Class. London: Victor Gollancz, 1963.

THOMPSON, Heather Ann. "The Prison Industrial Complex: A Growth Industry in a Shrinking Economy." New Labor Forum, vol. 21, no. 3, 2012, p. 38-47.

WACQUANT, Loïc. Punishing the Poor: The Neoliberal Government of Social Insecurity. Durham: Duke University Press, 2009.

WARREN, Susan. “Ocasio-Cortez Blasts Capitalism.” Bloomberg.com, 10 March 2019, www.bloomberg.com/news/articles/2019-03-10/ocasio-cortez-blasts-capitalism-as-anirredeemable-system.

Accessed 28 January 2021.

WEAVER, Timothy P.R. Blazing the Neoliberal Trail Urban Political Development in the United States and the United Kingdom. Philadelphia: University of Pennsylvania Press, 2016.

WEEMS, Robert E, Jr. "The Revolution Will Be Marketed: American Corporations and Black Consumers During the 1960's." Consumer Society in American History: A Reader. Ed. Lawrence B. Glickman. Ithaca: Cornell University Press, 1999, p. 316-325.

WILLIAMS, Eric. Capitalism and Slavery. 1944. Chapel Hill: University of North Carolina Press, 2021.

WILLIAMS, Rhonda Y. The Politics of Public Housing: Black Women's Struggles against Urban Inequality. New York: Oxford University Press, 2004.

ZAKIM, Michael, and Gary J. KORNBLITH (eds.). Capitalism Takes Command: The Social Transformation of Nineteenth-Century America. Chicago: University of Chicago Press, 2012.

ZEBALLOS-ROIG, Joseph. “Warren Buffett Says He Agrees with Bernie Sanders.” Markets Insider, 24 February 2020,

markets.businessinsider.com/news/stocks/warren-buffett-agree-bernie-sanders-capitalismregulation-socialism-election-vote-2020-2-1028932198.

Accessed 28 January 2021.

ŽIŽEK, Slavoj. “Occupy First. Demands Come Later.” The Guardian, 26 October 2011, www.theguardian.com/commentisfree/2011/oct/26/occupy-protesters-bill-clinton. Accessed 28 January 2021.

\section{NOTES}

1. These workshops, organized by the editors along with Caroline Rolland-Diamond (Université Paris Nanterre), David Huyssen (University of York), Gareth Millington (University of York), and Thomas Sugrue (New York University), were as follows: "Environmental Histories of Capitalism: Land, Race, and Profit" on 14 November 2017; "Political Culture and Political Movements in the Neoliberal City" on 15 December 2017; "Détailler l'histoire du capitalisme américain, vu d'en bas" at the French Association for American Studies' (AFEA) Annual Meeting on 25 May 2018. Support for the project was provided by Sorbonne Université (HDEA), the Université Paris Nanterre (CREA), the University of York, and New York University.

2. A few notable exceptions of canonical works in the "new history of capitalism" that deal with the postwar era are: Bethany Moreton, To Serve God and Wal-Mart: The Making of Christian Free 
Enterprise (2009); Kim Phillips-Fein, Invisible Hands: The Businessmen's Crusade against the New Deal (2009).

3. The one work in this area that has been sporadically acknowledged as belonging to the "new history of capitalism" project is N.D.B. Connolly's fine study on race and real estate, A World More Concrete: Real Estate and the Remaking of Jim Crow South Florida (2014).

4. Taylor uses the term "predatory inclusion" to describe the role of the state in the extension of real estate capitalism into formerly excluded segments of racialized markets.

5. Elizabeth Tandy Shermer's contribution to the Journal of American History "Interchange" is the only one to evoke the key place of histories of postwar populism in the "new history of capitalism," but such histories were entirely absent four years later, for example, in Beckert and Desan's field-defining collection. Two fine studies on the grassroots politics of consumer rights, colorblindness, and meritocracy are: Matthew D. Lassiter, The Silent Majority: Suburban Politics in the Sunbelt South (2006); Kevin Kruse, White Flight: Atlanta and the Making of Modern Conservatism (2006). On "laissez-faire racism," see Bobo et al. On "race-inflected neoliberalism," see Dawson.

6. While this new wave of work is very recent, the University of Chicago's Race and Capitalism project has been around since 2015, when political scientists Michael Dawson and Megan Ming Francis launched the initiative because of, in their assessment, "how few spaces existed within the scholarly and public spheres that [...] examined the mutually constitutive structures of capitalism" (Dawson and Ming).

7. The idea of a rather abrupt neoliberal turn in the 1970s is most associated with the work of David Harvey.

\section{ABSTRACTS}

Over the past decade or so, the concept of capitalism has exploded within the domains of popular culture and mainstream political discourse in the United States, a phenomenon driven forward by the visibility of anticapitalist movements like Occupy Wall Street, the appearance of bestselling books like Thomas Piketty's Capital in the Twenty-First Century and blockbuster movies like The Big Short, and the meteoric rise of nationally prominent democratic socialist politicians like Bernie Sanders and Alexandria Ocasio-Cortez. Such circumstances spurred the development of what has quickly become one of the most vibrant subfields in the US historical profession-the so-called "new history of capitalism." Following the publication in 2013 of a front-page New York Times article covering this new subfield, historians identifying with the project contributed to a range of field-defining essays and exchanges explaining its origins and inspirations, its innovations, and its importance. The essay to follow introduces the thematic dossier by building upon a number of recent critiques of the conceptual flaws and historical blind spots revealed by the exchanges that have laid down the groundwork of the "new history of capitalism." It argues that this subfield needs to move towards a more meaningful engagement with the social and the cultural, and to incorporate the contributions of recent work on racial capitalism, neoliberalism, the environment, the carceral state, and gender and sexuality in the twentieth-century United States.

Depuis une dizaine d'années environ, le concept de capitalisme a fait un retour fracassant aux États-Unis, aussi bien dans les discours politiques que dans la culture populaire. Ce phénomène est le produit de la grande visibilité médiatique de mouvements anticapitalistes, tels qu'Occupy 
Wall Street, de la publication de best-sellers comme Le Capital au XXI siècle de Thomas Piketty et du succès retentissant de films tels que The Big Short, ainsi que de la montée en puissance sur la scène nationale d'hommes et de femmes politiques socialistes comme Bernie Sanders et Alexandria Ocasio-Cortez. C'est dans ce contexte que s'est développé l'un des sous-champs les plus dynamiques de la profession historienne aux États-Unis: la «nouvelle histoire du capitalisme ». À la suite de la publication en 2013, en première page du New York Times, d'un article consacré à cette nouvelle tendance, un certain nombre d'historien•nes associé•es à ce projet ont publié une série d'essais et de tables-rondes cherchant à définir ses origines, ses inspirations, ses innovations et son importance. Cet essai introductif prend en compte un certain nombre de critiques récentes qui ont pointé du doigt les problèmes conceptuels et les anglesmorts de la "nouvelle histoire du capitalisme », telle qu'elle a été définie jusqu'à maintenant. Nous affirmons que ce sous-champ doit davantage prendre en compte le social et le culturel, et intégrer les contributions récentes consacrées au capitalisme racial, au néolibéralisme, à l'environnement, à l'État carcéral et au genre et aux sexualités dans les États-Unis du xx siècle.

\section{INDEX}

Keywords: capitalism, historiography, neoliberalism, racial capitalism, environment, carceral state, gender and sexuality

Mots-clés: capitalisme, historiographie, néolibéralisme, capitalisme racial, environnement, État carcéral, genre et sexualités

\section{AUTHORS}

ELSA DEVIENNE

Northumbria University

\section{ANDREW DIAMOND}

Sorbonne Université 